\title{
Diego Marmorio, Balzac e gli spettri fotografici
}

\section{Marco Stupazzoni}

\section{(2) OpenEdition}

\section{Journals}

\section{Edizione digitale}

URL: http://journals.openedition.org/studifrancesi/1555

DOI: 10.4000/studifrancesi. 1555

ISSN: 2421-5856

\section{Editore}

Rosenberg \& Sellier

\section{Edizione cartacea}

Data di pubblicazione: 1 novembre 2014

Paginazione: 618

ISSN: 0039-2944

\section{Notizia bibliografica digitale}

Marco Stupazzoni, « Diego Marmorio, Balzac e gli spettri fotografici », Studi Francesi [Online], 174 (LVIII I

III) | 2014, online dal 01 novembre 2014, consultato il 18 septembre 2020. URL : http://

journals.openedition.org/studifrancesi/1555; DOI : https://doi.org/10.4000/studifrancesi.1555

\section{Questo documento è stato generato automaticamente il 18 settembre 2020.}

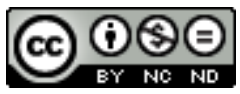

Studi Francesi è distribuita con Licenza Creative Commons Attribuzione - Non commerciale - Non opere derivate 4.0 Internazionale. 


\title{
Diego Marmorio, Balzac e gli spettri fotografici
}

\author{
Marco Stupazzoni
}

\section{NOTIZIA}

DIEGO MARMORIO, Balzac e gli spettri fotografici, in Scrittori e fotografia. Un magnifico inizio. 1840-1870, Roma, Edizioni Postcart, «Scrittori e fotografia», 2013, pp. 60-66.

1 Nell'ambito delle riflessioni che, in questo volume, l'autore sviluppa intorno ai rapporti ed alle influenze tra fotografia e creazione letteraria, si inserisce questo breve saggio dedicato a Balzac e, in particolare, al capitolo XXXII de Le Cousin Pons nel quale lo scrittore riflette sui rapporti tra mondo morale e mondo materiale avvalendosi della metafora dello spettro afferrato dal dagherrotipo.

2 In un articolo poi compreso nel volume: Quando ero fotografo, Nadar si chiede se il terrore di Balzac davanti al dagherrotipo (cf. Louis-Auguste Bisson, Ritratto di Honoré de Balzac, 1842) fosse sincero o simulato. Susan Sontag (cf. Sulla fotografia) ritiene che questa paura fosse autentica: per Balzac, infatti, il procedimento fotografico era un modo per materializzare, ingrandendoli, quei minuscoli particolari che nella scrittura narrativa e, quindi, nella sua opera letteraria, riassumevano, in apparizioni momentanee, una vita intera. 